
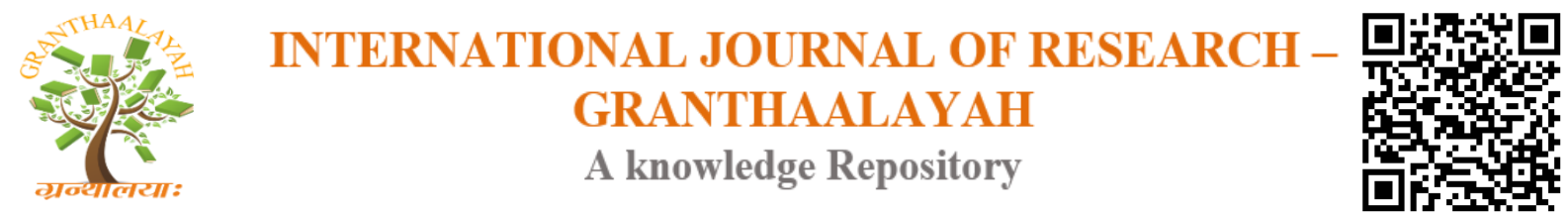

Social

\title{
THE DEPICTION OF VILLAGE LIFE AND THEIR PROBLEMS IN 'GODAN' BY PREMCHAND AND 'GAMPERALIYA' BY A SRI LANKAN NOVELIST MARTIN WIKRAMASINGHA
}

\author{
Dr. RKD Nilanthi Kumari Rajapaksha *1 \\ ${ }^{*}$ Senior Lecturer in Hindi, Department of Languages, Cultural and Performing Arts, University \\ of Sri Jayewardenepura, Gangodawila Nugegoda, Sri Lanka
}

\begin{abstract}
Godan was written in India in 1936 by Premchand. Gamperaliya was written in Sri Lanka in 1944 by Martin Wickramasinghe. Both the writers are from different countries, yet many similarities are found in their Novels. Being contemporaries has immediate effect on the content of both Writers. The purpose of this study was to find those similarities. After study of both novels, often many similarities could be found such as blind beliefs, poverty and the habits of the rural population.
\end{abstract}

Keywords: Premchand; Godan; Martin Wickramasinghe; Gamperaliya; Village Life.

Cite This Article: Dr. RKD Nilanthi Kumari Rajapaksha. (2017). "THE DEPICTION OF VILLAGE LIFE AND THEIR PROBLEMS IN 'GODAN' BY PREMCHAND AND 'GAMPERALIYA' BY A SRI LANKAN NOVELIST MARTIN WIKRAMASINGHA." International Journal of Research - Granthaalayah, 5(11), 46-49. https:// doi.org/10.29121/granthaalayah.v5.i11.2017.2325.

\section{Introduction}

The main objective of this study is to carry out a critical analysis of the Noel 'Godan' by Indian writer 'Premachand' and 'Gamperaliya' by Sri Lankan writer, Martin Wickramasinghe to figure out how Problems related to the prostitutes are depicted. Many researchers have been already conducted on the works of Premchand and Martin Wickramasinghe separately. However, no comparative research has been found in the representation of this problem in their Novels.

\section{Materials and Methods}

The main method of research in this study was textual analysis of 'Godan' by Premachand and 'Gamperaliya' by Martin Wickramasinghe. In order to find out how Problems related to the rural population are portrayed in their Novels, the following steps have been followed, 
A close-reading of 'Godan' by Premachand and 'Gamperaliya' by Martin Wickramasinghe deeply, collecting data; Completing the Comparative Analysis and making conclusions.

\section{Results and Discussions}

Godan was written in 1936. The depiction of the village in Godan is as follows:

"What was the village, it was Providence, ten to twelve houses, whose roof was halftiled, and collapsing further."1

Gamperaliya was written in 1944. The people of Koggala village located in District Gall, in the south region of Sri Lanka, is the subject matter of this novel. In this village there are elite and illiterate, ordinary people. The author has accurately portrayed them.

Poverty is a big problem for the Indian villagers, and the self-contemplation of Dhaniya is an example for this -

"Three boys died in childhood. Her mind still says, If she had provided them with medicines, they would have survived, but she could not get the medicine due to poverty." 2

Hori, the main character of the novel, 'Godan', is suffering extreme poverty:

"Even though Hori had to pay the entire barn of this crop, there was still a loan of three hundred rupees remaining, and an addition of a hundred rupees as interest. Five years ago, he had taken sixty rupees to purchase a bull, he had paid it, but the sixty rupees is still remaining because of the interest added. Hori had grown potatoes with the money thirty rupees taken from Pandit Daatadin. The potatoes were dug up by thieves, and he completed paying it on installments, in the three year period, a hundred rupees had been added as interest."

Thus, Mr. Shah gets Hori's harvest auctioned, because Hori is his debtor. Daatadin makes him his worker and takes 200 rupees for a loan of 30 rupees. Hori had a strong desire to buy a cow, yet his desire was not fulfilled till his death.

"And this was not just Hori's condition. This was a disaster in the whole village. There is no person who does not cry."4

Poverty is a serious problem of the Sri Lankan village too. Martin Wikramasingha has also illustrated this issue in his Novel 'Gamperaliya'.

\footnotetext{
${ }^{1}$ Premchand, Godan, 2005, p.141

${ }^{2}$ Do, 2005, p.09

${ }^{3}$ Do, p.39

${ }^{4}$ Premchand, Godan, 2005, p.357
} 
'Matara Hamine' becomes widow after the death of 'Kaisaruwatthe Muhandiram'. She faces a terrible economic crisis. Due to the superiority Complex, she does not seek help from others. But in the depiction of the situation of the bungalow, the author indicates their economic downturn as follows:

"By spreading coconut leaves on the broken part of the roof, it was prevented from getting wet inside the house. Due to the crack in the wall, some portions of the living room were got wet. There is a possibility of spending two to three thousand rupees to rebuild the terrace. 'Matara Hamine' could not spend even fifty rupees, but due to superiority Complex, she did not ask for the help of 'Pial',.,5

Due to poverty, they are sometimes forced to do things improper to their situations:

"Nanda's husband Jinadasa was from a noble family. Due to being poor, he needs to borrow money to treat Nanda's disease. Due to insufficiency of money, he mortgaged Nanda's jewelry.",6

"Jinadasa, suffering from poverty, thought to do business:

Nanda, I'm going away to do some business.

From where did you get the money to do business?

I obtained a few bucks by mortgaging my land.",7

Thus, due to poverty, Nanda's husband had to mortgage his land, leave his wife and go away, and had to suffer and die there.

Ancient Indian villagers were affected by blind faith, because of which they were troubled.

Hori is the prime example:

"What can we do when God has made us slaves?"8

"Small and big people are made in the house of God. The person, who does pay great penance, enjoys the property. They might have done good deeds in their previous births, thus, they are enjoying happiness. If we do not do anything good, will we?"9

Sri Lankan villagers also have resorted by blind beliefs in leading their lives.

"When a villager is sick, they take treatments from another religious person in addition to the doctor. When 'Nanda' was ill the same method was followed."10

"After hearing the prophecy, Muhandiram started to believe that Piyal had given something to attract Nanda."11

\footnotetext{
${ }^{5}$ Wickramasinghe, Martin, Gamperaliya, 2015 (47 ${ }^{\text {th }}$ Edition), p.216

${ }^{6}$ Do, p.119

${ }^{7}$ Do, p.123

${ }^{8}$ Premchand, Godan, 2005, p.21

${ }^{9}$ Premchand, Godan, 2005, p.23

${ }^{10}$ Wickramasinghe, Martin, Gamperaliya, 2015 (4 $7^{\text {th }}$ Edition), p.64

${ }^{11}$ Do, p. 66
} 
The village girls do not have any relationship with any young man without the permission of their parents. When Piyal proposes to Nanda, Nanda tells Piyal to ask from her Mother first-

"Ask my mother.

I'll ask, but first, tell me whether you agree or not.

If my mother agrees, then I will too."12

This dialogue shows that girls cannot decide on their marriage in the village.

There was another problem for the villagers to get addicted to alcohol. Katrina's husband Punchchi Appu is an example for this. Due to being drunk, he used to do things unsuitable for a father. He stimulates carolis who was a servant of the muhandiram to his daughter Lisa and he spends the same on liquor -

"Muhandiram- When I told Corolis that I would hand him over to the police, he spawned everything. He has done all with the desire of having Lisa. Puanchi Appu used to cheat Carollis and take money from him."13

Puchi Appu's wife, Katrina was ill. For the sake of bringing medicine for her, Punchi Appu used to ask the people for money. Almost half of the money he spends on drinking alcohol:

"Piyal- I gave twenty-five rupees to Punchi Appu to get the medicine for Katrina. Mother told me that he has spent a half of that money on drink."14

At the end, Punchi Appu also sells his goods to drink alcohol:

"Punchi Appu said that he had to spend half of the amount he got selling the doors of his house, for Katrina's medicine, and the other half on alcohol.", 15

\section{Conclusions}

Thus, the Indian novel 'Godan' by Premchand and Sri lankan novel 'Gamperaliya' by Martin Wickramasinghe, depict the blind beliefs, poverty and the habits of the rural population, in which often many similarities can be found.

\section{References}

[1] Wickramasinghe, Martin. Gamperaliya. $47^{\text {th }}$ ed. Colombo: Publishers; 2015

[2] Premchand., Godan., New Delhi: Rajpal and Sons; 2005

*Corresponding author.

E-mail address: nilanthiraj1@ gmail.com

\footnotetext{
${ }^{12}$ Do, p. 25

${ }^{13}$ Do, p.61

${ }^{14}$ Do, p. 148

${ }^{15}$ Do, p. 149
} 